\title{
Changing Roles of Innovation and Imitation in Industrial Development: The Case of the Machine Tool Industry in Taiwan*
}

Tetsushi Sonobe

Foundation for Advanced Studies on International Development

Momoko Kawakami

Institute of Developing Economies

Keijiro Otsuka

Foundation for Advanced Studies on International Development

\section{Introduction}

It has been recognized in the endogenous growth literature that informational externalities or spillovers among enterprises are an important source of sustained economic growth. ${ }^{1}$ The potential importance of information spillovers has also been recognized by economic geography and location theory, beginning with the seminal work by Alfred Marshall and followed by a large number of theoretical and empirical studies that attempt to explain the advantages of large cities and industrial clusters. ${ }^{2}$ In the literature on economic development, too, since Joseph A. Schumpeter, the role of spillovers or imitations has been widely understood as a critical process by which new ideas are spread from innovators to followers. ${ }^{3}$

Despite such widely shared recognition and interests, solid micro-level empirical studies have seldom attempted to explore the evolutionary process of innovations and imitations in the course of industrial development. ${ }^{4}$ In fact, researchers have rarely asked even the simple questions of who the imitators are, how the imitations take place, and how effective these imitations have been. More important, they have generally failed to assess the importance of imitations for output expansion and productivity growth in the process of industrial development. This matter may be particularly important when considering the economic growth of "high-performing" East Asian economies, which is accounted for mostly by rapid capital accumulation but little by

(C) 2003 by The University of Chicago. All rights reserved.

0013-0079/2004/5201-0005\$10.00 
technological progress. ${ }^{5}$ In these economies, where enterprises have proliferated in number in the course of rapid industrial development, information spillovers from incumbents to new enterprises have no doubt taken place. While information spillovers from the leading enterprises to other existing enterprises will improve the average productivity of an industry, those from incumbents to new entrants may lower it if the latter are less productive. Thus, the extent to which the entry of new enterprises has contributed to productivity growth as well as output growth in East Asia needs to be examined carefully.

Using data from individual enterprises collected by our own surveys and obtained from export statistics, this study attempts to analyze the changing roles of imitations, as well as innovations, in the development process of the machine tool industry in Taiwan. As latecomers to the machine tool industry, Taiwanese manufacturers have relied heavily on technologies developed in other countries, particularly Japan and the United States. Yet the international transfer of new technology requires substantive domestic efforts to assimilate and adapt the new technologies to local conditions through trial and error. ${ }^{6}$ Pioneers who made risky attempts to introduce the new technologies and production methods may be termed "innovators." Thus, not only the start of machine tool production during the 1940s and 1950s but also the introduction of numerically controlled (NC) machine production since the late 1970s and the adoption of a mass production system based heavily on subcontracting since the early 1980s can be regarded as "innovations" that have had a pervasive impact on the growth and structure of the machine tool industry in Taiwan.

From published secondary data, it appears that productivity growth in this industry was stagnant in the early stage of its development when the industrial output was growing most rapidly. Based on our own enterprise survey, we contend that there was an active entry of a swarm of low-productivity enterprises at this stage, which lowered the productivity growth of the industry as a whole. In later stages, when such entry decreased, however, imitations among the existing enterprises contributed positively to productivity growth. In this article, we analyze the changing roles of imitations by identifying the characteristics of the imitators and innovators and by describing the changing ways in which innovations took place over time.

The remainder of this article is organized as follows. In Section II, we identify three major innovations in the history of the machine tool industry in Taiwan. In Section III, using a simple two-period model, we examine the pattern of productivity growth and demonstrate the possibility of output growth without significant productivity growth. In Section IV, we classify sample enterprises into four groups, namely, pioneers, followers, new pioneers, and new followers, and we describe the performances of these groups in terms of the average value of production and export, $\mathrm{NC}$ ratio, and the value of products per unit of weight as a quality indicator. In order to test several hypotheses regarding heterogeneity among these groups in productivity and the ability to imitate, in Section V, we estimate a series of reduced-form functions ex- 
plaining the values of the production and export of the sample enterprises as well as other performance indicators. The conclusions and policy implications of this study are discussed in Section VI.

\section{Innovations and Growth in the Machine Tool Industry}

In the half-century long history of machine tool production in Taiwan, there have been three watersheds that have altered the manner of competition among manufacturers. ${ }^{7}$ These are (1) the beginning of the production of conventional machine tools in the late 1940s, (2) the initiation of the production of NC machines in the latter half of the 1970s, and (3) the introduction of mass production of highly standardized machine tools in the early 1980s. The purpose of this section is to review briefly the development of these innovations.

\section{A. Initiation of Production}

The attempt to produce conventional machine tools in Taiwan was started in the late 1940s by mechanical engineers and blue-collar workers in traditional ironworks and other machinery industries. Such enterprises of this early period may be regarded as "early innovators" or "pioneers," as they struggled to manufacture new products for more than a decade in the underdeveloped economic conditions of the late 1940s to the early 1960s. The success of these enterprises in manufacturing marketable machines during this period made them the leading machine tool enterprises during subsequent periods, and some of them were still among the largest and most prosperous enterprises in the late 1990s.

The early development of the machine tool industry was constrained by stagnant domestic demand. Although a gradual expansion of exports under the export-oriented industrialization policy scheme after the 1960s promoted the growth of the Taiwanese economy, increased production of conventional machine tools had to wait until the mid-1970s when a swarm of new enterprises entered the industry to exploit the newly emerging business opportunities. Many of these enterprises were spin-offs from the pioneering enterprises and produced accurate copies of the originals. ${ }^{8}$ Thus, these companies may legitimately be called "followers."

Such an active entry of followers in the late 1970s and the early 1980s probably had a significant bearing on the development of interfirm division and specialization of labor, as envisaged in the classical article by George J. Stigler. ${ }^{9}$ Based on her field studies, conducted in 1974 and 1981, Alice H. Amsden observed that not only the assembly but also the production of the parts were carried out internally by machine tool enterprises in 1974; however, the transaction of parts and intermediate products between assemblers and part suppliers become dramatically active by $1981 .{ }^{10}$ Interfirm division and specialization of labor was particularly developed in the area around Taichung city, where more than half of the Taiwanese machine tool enterprises are clustered. As the literature on economic geography suggests, even new enterprises with insufficient technical expertise and funds for initial investments 


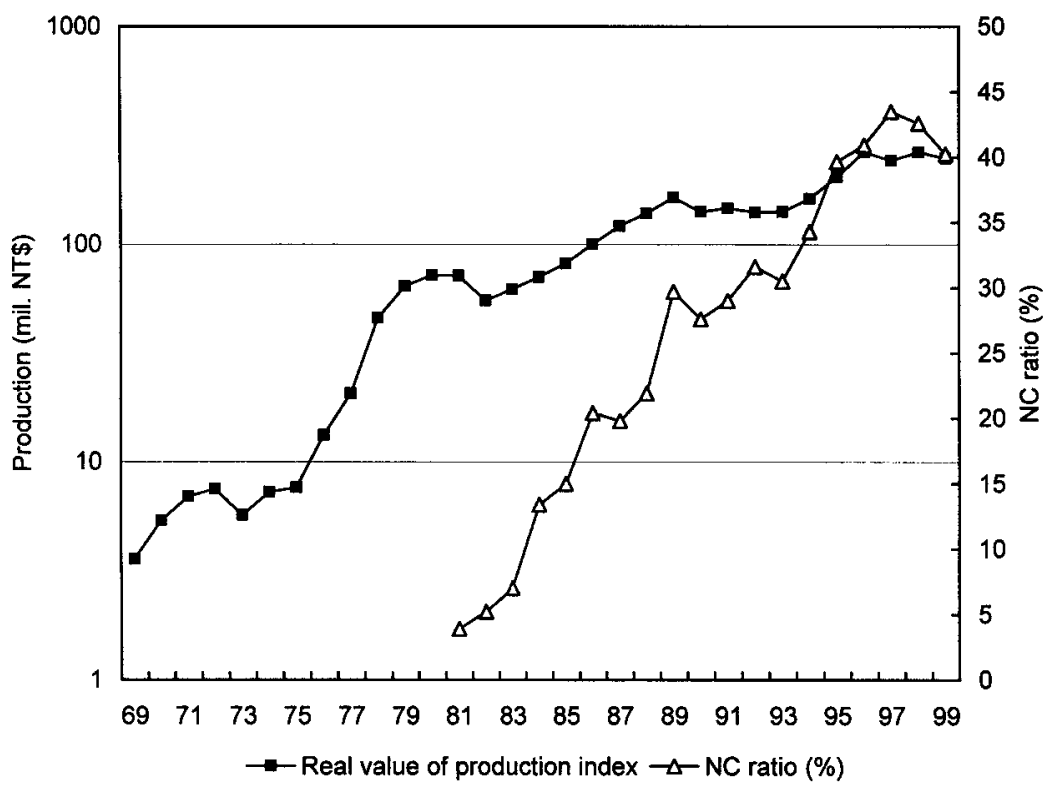

FIG. 1.-Changes in the real value of production and NC ratio. Sources: For value of production, Japan Machine Tool Builder's Association, Kousaku Kikai Tokei Yoran (Machine tool statistical data book) (Tokyo: Japan Machine Tool Builder's Association, various years), data originally from the Taiwan Association of Machinery Industry; for NC ratios, 1981-94, Taiwan Association of Machinery Industry, Jixie Gongye 50 Nianshi (Fifty years of the machine industry) (Taipei: Taiwan Association of Machinery Industry, 1995), and for 1995-99, calculations by authors based on the production data from Taiwan Association of Machinery Industry, available at http:// www.tami.org/statistics/chart2.html, Taipei. The value of production is deflated by the wholesale price index of machinery and equipment, as reported by Council for Economic Planning and Development, Republic of China, Taiwan Statistical Data Book (Taipei: Council for Economic Planning and Development, various years).

can enter an industry by taking advantage of agglomeration economies arising from favorable access to technology information, parts and components, and skilled labor in industrial clusters. ${ }^{11}$ The emergence of an industrial cluster allows new entrants to grow in small steps by taking small and calculable risks, and their active entry, in turn, reinforces agglomeration economies. ${ }^{12}$

Figure 1 shows the trend of the real value of machine tool production since 1969, expressed in semi-log form, and the share of NC machines in the total production value of machine tools since 1981. From the figure, we can observe the accelerated growth of production in the latter half of the 1970s. On the supply side, this quantitative growth is attributable to the active entry of followers. On the demand side, the market opportunities for Taiwanese firms improved in this period as European and Japanese manufacturers shifted from the production of conventional machine tools to that of $\mathrm{NC}$ machines. 


\section{B. Production of NC Machines}

While the entry of followers was increasing in the late 1970s, early innovators were struggling to produce $\mathrm{NC}$ machines. The basic technology for producing NC machines was not totally unknown to them by the mid-1970s since these enterprises had used NC machines imported from Japan. At that time, Japanese manufacturers had already profited from the massive fabrication of NC lathes and machining centers. ${ }^{13}$ According to our own interviews, however, the early production of NC machines in Taiwan from the mid-1970s to the early 1980s entailed a lot of technical difficulties because of the paucity of engineers adept at the interface between mechanical and electrical systems.

The first NC lathe and the first machining center were produced by Yang Iron in 1974 and 1979, respectively, whereas the first NC milling machine was produced by Yoeng-chin in 1979. A large Japanese manufacturer of NC controllers assisted local machine tool producers to solve the technical difficulties in the integration of mechanical and electrical technologies. The quest for $\mathrm{NC}$ machines resulted in the remarkable increase in the share of $\mathrm{NC}$ machines in the total value of production from $7 \%$ in 1983 to $28 \%$ in 1990 (see fig. 1).

\section{Mass Production of Standardized Products}

The opportunity to profit from NC machine production attracted a new type of enterprise that entered the industry around 1980 with the intention and ability to produce $\mathrm{NC}$ machines, as well as milling machines, in the beginning. These new entrants showed ingenuity in developing a new mass production system of standardized NC machines and utilizing specialized subcontractors effectively, while they themselves specialized in designing, assembling, and marketing. With this new system, these "new pioneers" succeeded in reducing the machine prices drastically without significantly reducing the quality of products. They were particularly successful in the production of machining centers, which could be more easily standardized than the NC lathe. ${ }^{14}$ Ten years after they were founded, the pioneers had grown into the two largest enterprises in the industry.

This new innovation was no less important than the beginning of the production of $\mathrm{NC}$ machines, and it has triggered widespread imitation since the late 1980s. First, many spin-offs from the two new pioneers founded new enterprises in the 1990s to become "new followers." Second, the early pioneers, who had accumulated technological and management capacities over time, also tried to reduce the prices of NC machines in the 1990s by adopting a mass production system based on subcontracting. They possessed, however, a comparative advantage in higher-quality conventional machines, so they continued to produce these in addition to standardized machining centers. An important observation from figure 1 is that output increased rapidly in the mid-1990s when the abolition of the Voluntary Restriction Arrangement on exports to the United States implemented during the period 1987-93 led to 
TABLE 1

Changes in the Number of Enterprises, Real Value Added, ANd TFP Index, 1954-96

\begin{tabular}{lccc}
\hline & Number of Firms & $\begin{array}{c}\text { Real Value Added } \\
(1986=100)\end{array}$ & $\begin{array}{c}\text { TFP Index } \\
(1986=100)\end{array}$ \\
\hline Level: & & & \\
1954 & 19 & .1 & N.A. \\
1961 & 38 & .9 & 63.2 \\
1966 & 161 & 100 & 88.3 \\
1986 & 787 & 230.9 & 100 \\
1991 & 1,915 & 352.0 & 116.6 \\
1996 & 2,374 & & 141.2 \\
Annual growth rate (\%): & 12.1 & 18.8 & 1.7 \\
$1961-86$ & 7.9 & 15.1 & .6 \\
$1966-86$ & 17.8 & 16.7 & 3.1 \\
$1986-91$ & 4.3 & 8.4 & 3.8 \\
$1991-96$ & & & \\
\hline
\end{tabular}

Sources. - Data are from Directorate-General of Budget, Accounting, and Statistics, Executive Yuan, Report on Industrial and Commercial Census (Taipei: Directorate-General of Budget, Accounting, and Statistics, Executive Yuan, various years). The deflator is the wholesale price index of machinery and equipment reported by the Council for Economic Planning and Development, Taiwan Statistical Data Book (Taipei: Council for Economic Planning and Development, various years).

Note. - N.A. $=$ not available.

active imitation, even though the growth rate declined from 1997 because of the outbreak of the Asian economic crisis.

\section{A Simple Accounting Model and Hypotheses}

In this section, we first outline the pattern of productivity growth of the machine tool industry as a whole, and, then, using a simple accounting equation, we link it with the history of innovations and imitations described in the previous section.

Table 1 shows changes in the number of machine tool enterprises, real value added, and the total factor productivity (TFP) index calculated using the data from the Industrial and Commercial Census of Taiwan (various years). Unfortunately, the data for the industry in the 1970s and the early 1980s are not available since machine tool enterprises were not distinguished from wood machinery enterprises in the censuses conducted in 1971, 1976, and 1981. It is interesting that the number of enterprises, which includes suppliers of parts and components, continued to increase even in the 1990s, that is, over 4 decades after the birth of the industry. ${ }^{15}$ Presumably, this is because of the continuous growth of the industry and the spread of mass production that relied on the division and specialization of labor among a large number of relatively small enterprises.

Because of the sheer paucity of data, we must admit that the calculation of the levels as well as the growth rates of TFP is crude. ${ }^{16}$ Nonetheless, it is worth noting that TFP growth was negligible during the period from 1966 to 1986 as compared with the spectacular growth of real value added. The pro- 
ductivity growth rate during this period may be biased downward, however, because the industry was booming in 1966 . The average annual rate of productivity growth from 1961 to 1986 , however, is as low as $1.7 \%$, which accounts for a mere $14 \%$ of the growth rate of real value added.

To conceptualize the effects of innovations and imitations on productivity growth, consider a two-period model in which new enterprises enter the industry with the average TFP level of $A_{N}$ and capture the market share of $\Theta$ in the second period. Incumbents' average TFP level in the second period is denoted by $A_{I}$ and that in the first period by $A_{I 0}$. Since the TFP level of the industry as a whole in the second period $(\bar{A})$ is written as

$$
\bar{A}=(1-\Theta) A_{I}+\Theta A_{N},
$$

its change is given by

$$
\begin{aligned}
\bar{A}-A_{I 0} & =(1-\Theta) A_{I}+\Theta A_{N}-A_{I 0} \\
& =(1-\Theta)\left(A_{I}-A_{I 0}\right)+\Theta\left(A_{N}-A_{I 0}\right) .
\end{aligned}
$$

Thus, the average productivity growth of the industry is a weighted average of the productivity growth of the incumbent group and the difference between the new entrants' productivity level and the incumbents' initial productivity level. ${ }^{17}$

This simple decomposition formula implies that overall productivity can decline if entrants are relatively inefficient (i.e., $A_{N}<A_{10}$ ), if their entry is sizable (i.e., large $\theta$ ), and if productivity improvements by incumbents are small (i.e., small $\left(A_{I}-A_{I 0}\right)$ ). We conjecture that most of these conditions were valid in the machine tool industry in the 1970s, when the incumbents were pioneers and the entrants were followers. The entry of followers was sizable in the late 1970s, as noted by Amsden. ${ }^{18}$ If the followers were less efficient than the pioneers because of imperfect imitation, then their entry could stagnate overall productivity growth. The fact that so many enterprises entered suggests, however, that followers successfully imitated the innovator's technologies and shared the innovators' original profits. The erosion of profit for an incumbent enterprise that lost a former employee associated with a spinoff and new entry would not have been large because all the enterprises sell most of their products to large international markets.

According to Martin N. Bailey et al., new entrants tend to be less efficient, although some are highly productive; diversity among enterprises in their productivities is quite large and persistent. ${ }^{19}$ Firms with low productivity can survive in those industries because returns to scale at the firm level are not large and are decreasing beyond the relatively small size ranges. Diseconomies of scale can set in easily in machine tool production because the production process is highly labor intensive and often unstandardized and the monitoring of workers is costly. Thus, producers have small-sized operations, and these tend to remain small. Since we do not have the relevant enterprise-level data 
for the late 1970s, we cannot directly examine if these arguments apply to the followers in the machine tool industry in Taiwan. Instead, using the available data for the 1990s while assuming that the efficiency difference persists over the extended periods, we propose to test whether the pioneers are managerially and technologically more efficient than the followers. Specifically, we postulate the following hypothesis:

Hyротнеsis 1. The pioneers are larger in the size of operation and faster in the adoption of new technologies than the followers, and the quality of the pioneers' products is higher than that of the followers because of the superior managerial and technical abilities of the former over the latter.

Throughout the 1980s, the pioneers increased the production of NC machines, and in the latter half of the decade, the followers began imitating NC machine production. Thus, these two groups of incumbents would have made productivity gains, and, hence, the first term in the decomposition equation (2) would be positive in this period. Entrants in the 1980s also include the new pioneers who entered with the intention and ability to produce NC machines. According to our interviews with the top managers of 30 machine tool enterprises, the new pioneers were quite efficient in machine tool production from the beginning. Thus, it is uncertain a priori whether or not the average productivity of entrants was higher than that of incumbents. ${ }^{20}$ However, in view of the relatively high average rate of TFP growth in the late 1980s (shown in table 1), the relative productivity of the entrants (or the second term in [2]) would not have been very low. More specifically, we hypothesize the following relationships:

HYPOTHESIS 2. The new pioneers are larger in size of operation and faster in adoption of new technologies than the followers because of the superior managerial and technical abilities of the former as compared with the latter.

In the 1990s, the early pioneers became imitators of the mass production of cheap and standardized NC machines. In addition, the old followers, those who had entered in the 1970s and the 1980s, followed suit. These active imitations by incumbents must have contributed to the fast productivity growth observed during the period 1991-96, in contrast to the slowdown of the growth of real value added (see table 1). Turning to the effect of productivity difference between incumbents as a whole (i.e., the sum of pioneers, old followers, and new pioneers) and new entrants, it is again ambiguous whether the second term in equation (2) is negative or positive because the new followers, who were spin-offs from the new pioneers, might have been more efficient than the old followers. Similar to hypothesis 1 , however, the following hypothesis seems reasonable:

Hypothesis 3. The new followers are smaller than the new pioneers in size of operation, and the quality of the products of the former tends to be lower than that of the latter because of imperfect spillover effects.

Since we presume that the managerial and technical abilities of both earlier and new followers tend to be lower than those of the original pioneers, 
we expect that the imitation by the original pioneers tends to be more effective than the others. This argument can be summarized as follows:

HYPOTHESIS 4. The original pioneers are the most effective imitators in the 1990s.

\section{Data Source and Grouped Enterprise Performance}

A. Data Source

We conducted both informal and formal surveys in the cluster of machine tool manufacturers in the Taichung prefecture and Taichung city as well as the surrounding areas, including Chang-hua and Nantou prefectures, in the period 1999-2000. We visited 30 enterprises and conducted informal interviews to identify the major characteristics of this industry, the nature of historical development, and the manner of competition through innovations and imitations among enterprises. Based on such informal surveys, we prepared our own questionnaire and delivered it to 60 randomly selected machine tool enterprises. By repeated visits to those enterprises, we succeeded in collecting questionnaire forms from 49 enterprises. To our knowledge, this response rate was unusually high in Taiwan. We had to omit two enterprises from the analysis because their products are either for household use or special metal cutting purposes and, hence, are significantly different from those of other sample enterprises. ${ }^{21}$

While the sample enterprises provided answers to qualitative questions about the characteristics of managers at the time of founding and at present, many of them did not supply information regarding the cost of production, the importance of subcontracting, the prices of their products, and the relative proportion of conventional and NC machines. Furthermore, some enterprises did not even provide the data on the value of production.

Thus, we decided to rely on official export data by individual enterprises for the value of export as a proxy for the size of enterprise, the NC machine ratio, and the product prices. A desirable feature of this data set is that the value and quantity of exports are reported by type of machine tools. Using this information, we computed the unit price of each type of machine per kilogram, which is considered an appropriate measure of the quality of machine tools. ${ }^{22}$ The export data, however, are available only for 43 enterprises for 10 years from 1990 to 1999. In the statistical analyses below, we use the value of export, the $\mathrm{NC}$ ratio (the ratio of the value of exported $\mathrm{NC}$ machines to the total export value), and the unit prices of the products of these enterprises, in addition to the survey data of production. Figure 2 illustrates that the total value of machine tool exports from Taiwan moved in parallel with the total value of those moved by our 43 sample enterprises, suggesting that our sample selection was not greatly biased.

\section{B. Characteristics of Sample Enterprises by Group}

According to our classification, there are seven pioneer enterprises, 24 followers, two new pioneers, and 10 new followers, as shown in table 2. Pioneers 


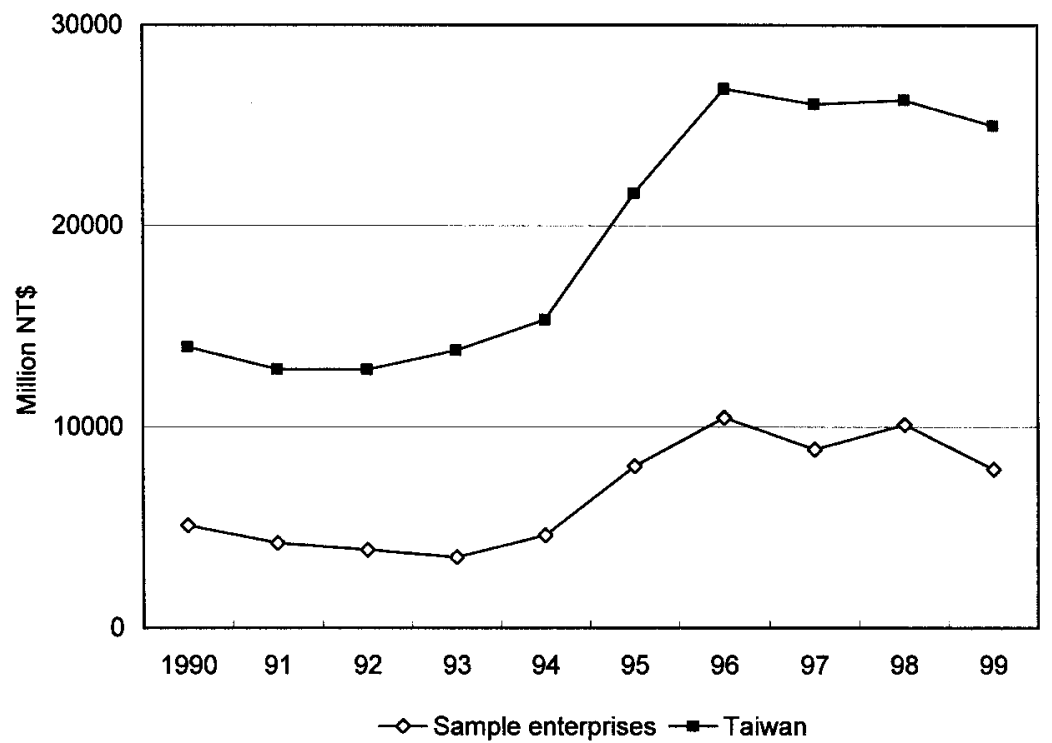

Fig. 2.-Changes in real value of machine tool export by the sample enterprises and by all enterprises in Taiwan. Sources: Data are from Statistical Department, Directorate General of Customs, Ministry of Finance, the Republic of China, Monthly Statistics of Exports, the Republic of China, Taiwan District (Taipei: Statistical Department, Directorate General of Customs, Ministry of Finance, the Republic of China, various years). Value of exports is deflated by the export price index of machinery and equipment, reported by the Council for Economic Planning and Development, Republic of China, Taiwan Statistical Data Book (Taipei: Council for Economic Planning and Development, Republic of China, various years).

are defined as those enterprises that were founded before 1969, and four out of the eight responding companies were founded by former machinists who had engaged in the production of some types of traditional machines earlier but not in the production of machine tools. On average, the pioneers were founded in 1957. Due partly to limited domestic demand, these pioneers started machine tool production on average 10 years after their foundings. The founders of the new pioneers had worked for other machine tool enterprises earlier and started the production of NC machines as early as the original pioneers, even though the latter were established more than 22 years earlier than the former. In contrast, the followers lagged behind in the initiation of NC machine production. The new followers, like the new pioneers, initiated NC machine production shortly after their founding.

The educational backgrounds of the founders vary considerably among the four groups. Many of the founders of the old pioneers were primary school graduates, whereas those of the new pioneers completed even graduate school. It is also clear that the founders of the early followers are more educated than those of the pioneers but less educated than those of the new followers. Over time, the average educational backgrounds of the founders rose, partly as a 
TABLE 2

Characteristics of Sample Enterprises at the Time of Their Founding by Enterprise Group

\begin{tabular}{|c|c|c|c|c|}
\hline & Pioneers & Followers & New Pioneers & New Followers \\
\hline Number of enterprises in enterprise group & 7 & 24 & 2 & 10 \\
\hline \multicolumn{5}{|l|}{ Time of major events: } \\
\hline Year of founding for enterprise (enterprise group range) & 1943-68 & 1966-89 & 1979-80 & 1990-97 \\
\hline Year of founding (enterprise group mean) & 1957.1 & 1979.3 & 1979.5 & 1994.1 \\
\hline Year of initiation of NC machine production (enterprise group mean) & 1980.6 & 1990.5 & 1980.5 & 1995.1 \\
\hline Years before MT production (enterprise group mean)* & 12.6 & .7 & 0 & 0 \\
\hline \multicolumn{5}{|l|}{ Previous occupations of founders $(\%)$ : } \\
\hline Machine tool enterprises & 0 & 59 & 100 & 90 \\
\hline Other machinery enterprises & 88 & 13 & 0 & 10 \\
\hline \multicolumn{5}{|l|}{ Educational background of founders $(\%)$ : } \\
\hline Primary school & 71 & 13 & 0 & 0 \\
\hline Junior high school & 0 & 12 & 0 & 0 \\
\hline High school (including college of technology) & 29 & 54 & 0 & 60 \\
\hline University or graduate school & 0 & 21 & 100 & 40 \\
\hline \multicolumn{5}{|l|}{ Relationship to founding partners $(\%): \dagger$} \\
\hline Kinship & 80 & 67 & 0 & 0 \\
\hline Friends & 40 & 50 & 100 & 56 \\
\hline Acquaintance though business & 0 & 33 & 50 & 67 \\
\hline Number of parts suppliers in the first full year of MT production (mean) & 19.0 & 29.6 & 40.5 & 38.7 \\
\hline
\end{tabular}

SOURCE. - Data are from our own survey.

* The number of years when enterprises were manufacturing parts and machines other than machine tools. Years when enterprises were engaged solely in trading businesses are excluded.

$\dagger$ Percentages of enterprises that had founding partners with the specified relationships. 
TABLE 3

Characteristics of Top Executive as of 1999 by Enterprise Group

\begin{tabular}{|c|c|c|c|c|}
\hline & Pioneers & Followers & New Pioneers & New Followers \\
\hline \multicolumn{5}{|l|}{ Relationship to founder: } \\
\hline The person himself & .29 & .75 & 1.00 & .90 \\
\hline Kinship & .43 & .17 & .00 & .00 \\
\hline Former employee & .00 & .04 & .00 & .00 \\
\hline Outsider & .28 & .04 & .00 & .10 \\
\hline Years of top management & 16.1 & 13.8 & 18.0 & 5.3 \\
\hline \multicolumn{5}{|l|}{ Previous occupations: } \\
\hline $\begin{array}{r}\text { Machine tool } \\
\text { enterprises }\end{array}$ & .57 & .63 & 1.00 & .90 \\
\hline $\begin{array}{l}\text { Other machinery } \\
\text { enterprises }\end{array}$ & .13 & .09 & .00 & .10 \\
\hline \multicolumn{5}{|l|}{ Educational background: } \\
\hline Primary school & .43 & .08 & .00 & .00 \\
\hline Junior high school & .15 & .09 & .00 & .00 \\
\hline $\begin{array}{l}\text { Senior high or special } \\
\text { high school }\end{array}$ & .14 & .58 & .00 & .60 \\
\hline $\begin{array}{l}\text { University or graduate } \\
\text { school }\end{array}$ & .28 & .25 & 1.00 & .40 \\
\hline
\end{tabular}

SouRCE. - Data are from our own survey.

result of the overall progress in education in postwar Taiwan, but this may also reflect the increasing importance of formal schooling in the management of enterprises in the later stages of the development of the machine tool industry.

As with other industries in Taiwan, machine tool enterprises are usually established by shared investments of a small group of founding partners, consisting usually of fewer than five people. As shown in table 2, kinship ties played an important role in forming the founding groups in earlier years, whereas it has now become common to raise funds from friends and acquaintances through business over time. Although we failed to obtain accurate information on the importance of subcontracting, the data on the number of parts suppliers in the first full year of machine tool production, shown in the last row of table 2, are informative. Reflecting the high rate of internal production, the pioneers purchased parts only from 19 part suppliers, but the early followers transacted with nearly 30 part suppliers, and both new pioneers and new followers did so with about 40 part suppliers. This is consistent with the results of our interviews with experienced managers, which indicated that the dependence on purchased parts has increased over time, particularly since the establishment of the mass production system in the 1980s.

As can be seen in table 3, the major characteristics of top executives as of 1999 were substantially different among the four groups. Five out of the seven pioneering enterprises had changed top executives, while most of the top executives among other enterprises were the founders themselves. As we will see later, the continued leadership by the aged founders with relatively 
TABLE 4

Export Performance by ENTERPRISe Group IN 1990 AND 1999

\begin{tabular}{|c|c|c|c|c|}
\hline & Pioneers & Followers & $\begin{array}{c}\text { New } \\
\text { Pioneers }\end{array}$ & $\begin{array}{l}\text { New } \\
\text { Followers }\end{array}$ \\
\hline \multicolumn{5}{|c|}{ Real value of exports (million NT\$): } \\
\hline 1990 & 369.5 & 42.4 & 786.3 & N.A. \\
\hline 1999 & 423.4 & 114.4 & 811.9 & 124.7 \\
\hline \multicolumn{5}{|l|}{ NC ratio: } \\
\hline 1990 & .51 & .21 & .84 & N.A. \\
\hline 1999 & .59 & .34 & .92 & .83 \\
\hline \multicolumn{5}{|c|}{$\begin{array}{l}\text { Real unit price of machining center } \\
\text { (NT\$): }\end{array}$} \\
\hline 1990 & 326.3 & 299.5 & 253.0 & N.A. \\
\hline 1999 & 245.5 & 234.0 & 242.7 & 233.0 \\
\hline \multicolumn{5}{|c|}{ Real unit price of NC lathe (NT\$): } \\
\hline 1990 & 419.6 & 329.0 & 302.2 & N.A. \\
\hline 1999 & 311.7 & 358.8 & 242.4 & N.A. \\
\hline \multicolumn{5}{|c|}{$\begin{array}{l}\text { Real unit price of conventional } \\
\text { machine (NT\$): }\end{array}$} \\
\hline 1990 & 172.8 & 154.0 & 125.1 & N.A. \\
\hline 1999 & 235.4 & 196.4 & 200.7 & 188.6 \\
\hline
\end{tabular}

Source. - Data are unpublished official statistics on exports of the Taiwanese government. NotE. - N.A. $=$ not available.

low educational backgrounds led to their adherence to the fabrication of lowand middle-grade conventional machines.

\section{Performance of Sample Enterprises by Group}

Table 4 shows the export performances by enterprise group in terms of the real value of exports per enterprise, $\mathrm{NC}$ ratio, and real unit price of machining center, NC lathe, and conventional machines in 1990 and 1999. ${ }^{23}$ As can be ascertained from this table, the new pioneers by far exceeded the other groups in terms of both average export value per enterprise and $\mathrm{NC}$ ratio. It is also interesting to observe that, in 1999, the early followers recorded a smaller average export value and a lower NC ratio than even the new followers. The dominance of the new pioneers is also confirmed from table 5, which reports the real value of production from the available survey data. It is noteworthy

TABLE 5

Real Value of Production by Enterprise Group

\begin{tabular}{lrccc}
\hline $\begin{array}{l}\text { Year (Number of } \\
\text { Observations) }\end{array}$ & Pioneers & Followers & New Pioneers & New Followers \\
\hline $1991(N=25)$ & 594.9 & 93.4 & $1,321.4$ & N.A. \\
$1995(N=28)$ & $1,321.4$ & 161.1 & $1,972.0$ & 127.3 \\
$1998(N=41)$ & $1,067.7$ & 198.2 & $1,519.4$ & 144.4 \\
\hline
\end{tabular}

SourCE. - Data are from our own survey.

NOTE. - N.A. $=$ not available. 
that, in terms of the growth rate of the real value of production, the two types of imitators (i.e., the pioneers and the followers) outperformed the new pioneers. This seems to confirm that imitation leads to the rapid growth of production.

Since the new followers had smaller values of production than the early followers but larger value of exports (see tables 4 and 5), it follows that export ratios were higher for the new followers. This is indicative of the poor performance of the old followers, who specialized in production primarily for saturated domestic markets as compared with huge overseas markets. The NC ratio is also lower for the followers than for the new pioneers and the new followers.

As for changes in unit prices, shown in table 4, we observe decreasing trends for machining centers and NC lathes, whereas the average price of conventional machines rose substantially. Apparently, Taiwanese machine tool exporters shifted to high-quality conventional machines in response to the rising wages in the island and the growing demand for upgraded products by Association of Southeast Asian Nations (ASEAN) countries, whereas they successively cut the prices of $\mathrm{NC}$ machines to penetrate into the middle-tier foreign markets. Of special interest is the fact that the unit prices of NC lathes and machining centers converged to the low level set by the new pioneers by 1990 as a result of the response of other enterprises, especially the original pioneers. It is also interesting to observe that the followers produced relatively cheap and low-quality conventional machines.

Figure 3 shows the changes in export value of the representative products by enterprise group for 1990-99. It is apparent that machining centers are the most rapidly growing product, the export of which has been dominated by the original and the new pioneers, as can be seen from figure $3 A$. According to figure $3 B$, these two groups have also been fairly strong at the export of $\mathrm{NC}$ lathes. The superior performance of the new pioneers is all the more outstanding as this group consists of only two enterprises. The early followers have specialized in conventional machines as can be seen from figure $3 C$.

In sum, the export performances of the four groups were substantially different in the 1990s. The old pioneers successfully responded to the price war triggered by the new pioneers, demonstrating their strong capability of imitating efficient rivals. In contrast, the old followers did not grow well in the 1990s, mainly due to the failure in shifting to the NC machines, nor did they successfully shift to the high-end conventional machine exports. The new pioneers had large shares in the export of two of the most important NC machines. The new followers entered the industry only after 1990, but they surpassed the old followers by imitating the strategy of the new pioneers but concentrating on lower-grade machining centers.

\section{Determinants of Enterprise Performance}

In this section, in order to test the hypotheses advanced in Section III, we estimate reduced-form regression equations for the size of enterprise operation, 


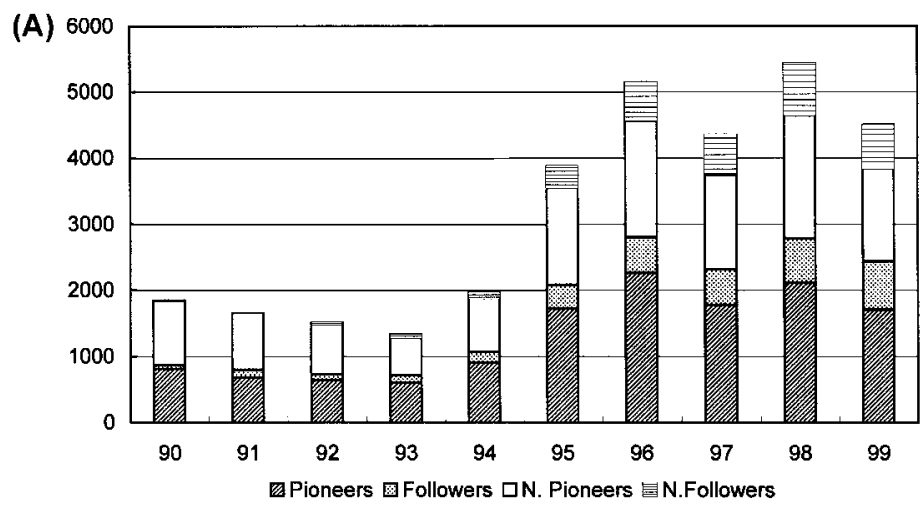

(B) 4000

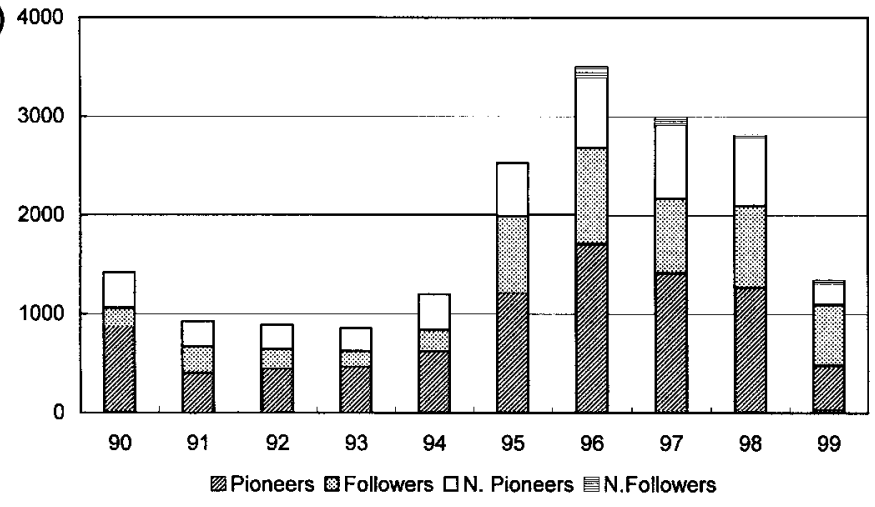

(C) 3000

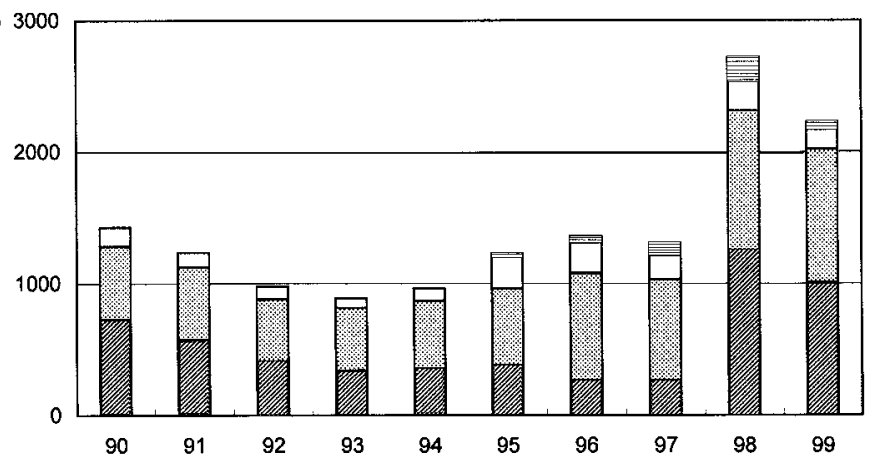

ש Pioneers Followers $\square$ N. Pioneers N.Followers

FIG. 3.-Changes in export values by product type by firm group, 1990-99. A, machining centers. $B, \mathrm{NC}$ lathes. $C$, conventional machines. 
$\mathrm{NC}$ ratio, and unit prices of machine tools. Assuming that the relative sizes of enterprise operation reflect differences in production costs and productivity levels, we use two dependent variables as proxies for operation size: the real value of production and the real value of export. The ratio of NC machine exports to total export value is used as a proxy for the ability to develop and assimilate new technology. Unit prices of conventional machines and machining centers per kilogram are considered to reflect both the quality and the production costs of these products. ${ }^{24}$

These regression equations have the same set of independent variables. Included are three dummy variables identifying the enterprise group to which an enterprise belongs, two other time-invariant variables (i.e., the type of founder and the first year of machine tool production), and several time-variant variables (i.e., the current top manager's schooling, relation of current top manager with founder, and length of service as a top manager). ${ }^{25}$ In addition, our specification allows for unobservable enterprise-specific effects and time effects.

Table 6 presents the results of the estimation of the operation size functions. The dependent variable in the first two columns is the logarithm of the real value of production, while that in the latter two columns is the logarithm of real export value. In column 1 of table 6 , which reports the random-effects estimates, both the follower dummy and the new follower dummy have negative and highly significant effects, indicating that the followers and the new followers are significantly smaller than the default group of the original pioneers. The new pioneers are as large as the original pioneers, controlling for other factors. Although the test statistics are not shown in the table, the new pioneers are significantly larger than both the early and new followers.

The spin-off dummy is equal to unity if the founder of the enterprise was a spin-off from a machine tool enterprise, and zero otherwise. For the new pioneers, however, the spin-off dummy is equal to zero, even though their founders were spin-offs. ${ }^{26}$ Spin-offs have slightly smaller firm sizes than other followers, but the differences are insignificant. The first year of machine tool production does not have a significant effect on the real value of production. Although the effects of the five time-invariant variables cannot be estimated separately in the case of the fixed-effects estimation, they can be viewed as parts of the enterprise specific effects, which can be obtained as the residual. In column 2, the group-wise averages of the estimated enterprisespecific effects are reported in the last four rows. Consistent with the estimated effects of the group dummies shown in column 1, the new pioneer group has the largest average magnitude of the fixed effects, followed by the early pioneer group, and then by the early follower group. According to the result of the Hausman's specification test, reported in column 1, the random-effect estimates are consistent.

The higher education of the current top manager tends to have positive but statistically insignificant effects on the size of the enterprise operation. The outsider dummy, which represents the kinship discontinuity in leadership, 
has an insignificant effect on the size of operation. Finally, the effect of the years of top management is positive in both columns and significant in column 1 , suggesting that the accumulation of firm-specific management know-how by the current top executives contributes to the growth in the size of operation.

The estimated effects of the first five variables shown in column 3 as well as the average magnitudes of the fixed effects shown in the last four rows in column 4 on the real value of exports are qualitatively the same as those on the real value of production. These results are consistent with the first part of hypothesis 1 -the pioneers are larger in operation size than the followers - and with the first parts of hypotheses 2 and 3-the new pioneers are larger than both the early and new followers. Unlike the first two columns, the last two columns show positive and significant effects of the outsider group, suggesting that those enterprises managed by outsiders tend to adopt an export-oriented strategy.

Table 7 shows the estimates of the NC ratio function. Since the dependent variable is censored at zero from below and at unity from above, the regression model is of the two-limit Tobit model. As is well known, however, this model is technically difficult to estimate if it is specified as a fixed-effects model. Since a semi-parametric estimator for the fixed-effects Tobit model developed by Bo E. Honoré is not applicable to our small sample, we decided to estimate the random-effects Tobit model. ${ }^{27}$ The first column presents the result of estimation using the full sample, and the next two columns compare the first and second halves of the period under study. Note that the estimates shown in column 1 of table 7 are not averages of those in columns 2 and 3, partly because the sample sizes are different and partly because some enterprises stop and resume the export of NC machines. Qualitatively, however, the estimation results are similar except for the effects of the outsider dummy.

The negative and highly significant effects of the follower dummy and the insignificant effects of the new pioneer dummy are consistent with our hypotheses that both the original and new pioneers are faster in the adoption of new technologies than the followers. The effect of spin-off is consistently negative and significant, suggesting that spin-off followers had difficulty in adopting the new technology even in the late 1990s. The positive and significant effect of the first year of machine tool production suggests that younger enterprises tend to have higher $\mathrm{NC}$ ratios. The effect of university education on $\mathrm{NC}$ ratio is positive and significant throughout the decade, but it declines in the second half. This result is consistent with the hypothesis that the importance of higher education in technology adoption declines as a new technology is diffused.

The outsider dummy has a positive and significant effect in the first period, reflecting the fact that the average $\mathrm{NC}$ ratio of those enterprises with this dummy equal to unity is far above the average $\mathrm{NC}$ ratio of the other enterprises. The effect of this variable, however, becomes negative and significant in the second period, reflecting the fact that three sample enterprises lost continuity in leadership in the late 1990s and the top managers from the 
TABLE 6

Determinants of Real Value of Production and Real Value of Exports

\begin{tabular}{|c|c|c|c|c|}
\hline & $\begin{array}{c}\ln \text { (Production) } \\
\text { Random Effects } \\
\text { (1) }\end{array}$ & $\begin{array}{c}\ln (\text { Production) } \\
\text { Fixed Effects } \\
\text { (2) }\end{array}$ & $\begin{array}{c}\ln (\text { Exports) } \\
\text { Random Effects } \\
\text { (3) }\end{array}$ & $\begin{array}{c}\ln \text { (Exports) } \\
\text { Fixed Effects } \\
\text { (4) }\end{array}$ \\
\hline Followers & $\begin{array}{c}-2.302 * * \\
(.635)\end{array}$ & N.A. & $\begin{array}{c}-2.251^{* *} \\
(.726)\end{array}$ & N.A. \\
\hline New pioneers & $\begin{array}{c}.005 \\
(1.038)\end{array}$ & N.A. & $\begin{array}{c}1.147 \\
(1.169)\end{array}$ & N.A. \\
\hline New followers & $\begin{array}{c}-3.031^{* *} \\
(.987)\end{array}$ & N.A. & $\begin{array}{c}-3.079 * * \\
(1.137)\end{array}$ & N.A. \\
\hline Spin-off & $\begin{array}{c}-.464 \\
(.504)\end{array}$ & N.A. & $\begin{array}{c}-.034 \\
(.543)\end{array}$ & N.A. \\
\hline First year of machine tool production & $\begin{array}{c}.049 \\
(.033)\end{array}$ & N.A. & $\begin{array}{l}.003 \\
(.037)\end{array}$ & N.A. \\
\hline High school & $\begin{array}{l}.286 \\
(.366)\end{array}$ & $\begin{array}{l}.387 \\
(.527)\end{array}$ & $\begin{array}{l}.502 \\
(.312)\end{array}$ & $\begin{array}{c}.798^{*} \\
(.349)\end{array}$ \\
\hline University & $\begin{array}{l}.834^{*} \\
(.424)\end{array}$ & $\begin{array}{l}.600 \\
(.518)\end{array}$ & $\begin{array}{c}.434 \\
(.342)\end{array}$ & $\begin{array}{l}.115 \\
(.368)\end{array}$ \\
\hline Outsider & $\begin{array}{l}.180 \\
(.495)\end{array}$ & $\begin{array}{l}.168 \\
(.662)\end{array}$ & $\begin{array}{l}1.058 * * \\
(.294)\end{array}$ & $\begin{array}{l}1.149 * * \\
(.296)\end{array}$ \\
\hline Years of top management & $\begin{array}{l}.029^{*} \\
(.013)\end{array}$ & $\begin{array}{l}.020 \\
(.014)\end{array}$ & $\begin{array}{l}.039 * * \\
(.011)\end{array}$ & $\begin{array}{l}.031 * * \\
(.011)\end{array}$ \\
\hline
\end{tabular}




\begin{tabular}{|c|c|c|c|c|c|}
\hline & Year dummies & $\begin{array}{l}\text { Two dummies for } \\
1995,1998\end{array}$ & $\begin{array}{l}\text { Two dummies for } \\
1995,1998\end{array}$ & $\begin{array}{l}\text { Nine dummies for } \\
\text { 1991-99 }\end{array}$ & $\begin{array}{l}\text { Nine dummies for } \\
\text { 1991-99 }\end{array}$ \\
\hline & Constant & $\begin{array}{c}-84.10 \\
(64.84)\end{array}$ & $\begin{array}{c}10.778^{* *} \\
(.418)\end{array}$ & $\begin{array}{r}5.794 \\
(73.03)\end{array}$ & $\begin{array}{l}9.728^{* *} \\
(.325)\end{array}$ \\
\hline & Number of observations & 94 & 94 & 351 & 351 \\
\hline & $\begin{array}{l}\text { Number of observations per enterprise } \\
R^{2}:\end{array}$ & 2.3 & 2.3 & 8.2 & 8.2 \\
\hline & Within & .408 & .416 & .406 & .412 \\
\hline & Between & .503 & .067 & .398 & .045 \\
\hline & Overall & .540 & .089 & .401 & .009 \\
\hline & $P$ value of Hausman test & .300 & N.A. & .319 & N.A. \\
\hline & $\begin{array}{l}P \text { value of } F \text {-test that fixed effect }=0 \\
\quad \text { for all } i \\
\text { Fixed effects. }\end{array}$ & N.A. & .002 & N.A. & .001 \\
\hline & Pioneer & N.A. & 1.862 & N.A. & 1.557 \\
\hline & Follower & N.A. & -.547 & N.A. & -.615 \\
\hline - & New pioneer & N.A. & 2.255 & N.A. & 3.049 \\
\hline N & New follower & N.A. & -.641 & N.A. & -.858 \\
\hline
\end{tabular}

SourCES. - The data for $\ln$ (production) for random effects and fixed effects are from our own survey. The data for ln(exports) for random effects and fixed effects are from unpublished official data on exports for Taiwan.

NOTE. - Numbers in parentheses are standard errors. N.A. = not applicable.

* Significant at the $5 \%$ level (one-tailed test).

** Significant at the $1 \%$ level (one-tailed test). 
TABLE 7

Determinants OF NC RATIO

\begin{tabular}{|c|c|c|c|}
\hline & $\begin{array}{c}\text { Random Effects, } \\
\text { Tobit } \\
(1990-99) \\
(1)\end{array}$ & $\begin{array}{c}\text { Random Effects, } \\
\text { Tobit } \\
(1990-94) \\
(2)\end{array}$ & $\begin{array}{c}\text { Random Effects, } \\
\text { Tobit } \\
(1995-99) \\
(3)\end{array}$ \\
\hline Followers & $\begin{array}{c}-.633 * * \\
(.058)\end{array}$ & $\begin{array}{l}-.391 * * \\
(.837)\end{array}$ & $\begin{array}{l}-.519^{* *} \\
(.064)\end{array}$ \\
\hline New pioneers & $\begin{array}{c}-.041 \\
(.074)\end{array}$ & $\begin{array}{l}.046 \\
(.068)\end{array}$ & $\begin{array}{l}.033 \\
(.083)\end{array}$ \\
\hline New followers & $\begin{array}{r}-.173 \\
(.111)\end{array}$ & N.A. & $\begin{array}{l}.113 \\
(.096)\end{array}$ \\
\hline Spin-off & $\begin{array}{l}-.153^{* *} \\
(.038)\end{array}$ & $\begin{array}{l}-.303 * * \\
(.040)\end{array}$ & $\begin{array}{l}-.127 * * \\
(.037)\end{array}$ \\
\hline $\begin{array}{l}\text { First year of mach } \\
\text { tool production }\end{array}$ & $\begin{array}{l}.019^{* *} \\
(.003)\end{array}$ & $\begin{array}{l}.013^{* *} \\
(.003)\end{array}$ & $\begin{array}{l}.014 * * \\
(.003)\end{array}$ \\
\hline High school & $\begin{array}{l}.022 \\
. .040)\end{array}$ & $\begin{array}{l}.008 \\
. .035)\end{array}$ & $\begin{array}{c}-.075 \\
(.053)\end{array}$ \\
\hline University & $\begin{array}{l}.196^{* *} \\
(.051)\end{array}$ & $\begin{array}{l}.168 * * \\
(.046)\end{array}$ & $\begin{array}{l}.128^{*} \\
(.062)\end{array}$ \\
\hline Outsider & $\begin{array}{l}-.193^{* *} \\
(.055)\end{array}$ & $\begin{array}{l}.319^{* *} \\
(.068)\end{array}$ & $\begin{array}{l}-.216^{* * *} \\
(.051)\end{array}$ \\
\hline $\begin{array}{l}\text { Years of top } \\
\text { management }\end{array}$ & $\begin{array}{c}.005^{*} \\
(.002)\end{array}$ & $\begin{array}{l}.005^{*} \\
(.002)\end{array}$ & $\begin{array}{l}.013 * * \\
(.002)\end{array}$ \\
\hline Year dummies & $\begin{array}{c}\text { Nine dummies for } \\
1991-99\end{array}$ & $\begin{array}{l}\text { Four dummies for } \\
\qquad 1991-95\end{array}$ & $\begin{array}{l}\text { Four dummies for } \\
1996-99\end{array}$ \\
\hline Constant & $\begin{array}{r}-36.56^{* * *} \\
(6.431)\end{array}$ & $\begin{array}{r}-25.97 * * \\
(6.486)\end{array}$ & $\begin{array}{r}-26.94 * * \\
(6.030)\end{array}$ \\
\hline $\begin{array}{l}\text { Number of } \\
\text { observations }\end{array}$ & 345 & 157 & 188 \\
\hline $\begin{array}{l}\text { Number of } \\
\text { observations } \\
\text { per enterprise }\end{array}$ & 8.2 & 4.8 & 4.7 \\
\hline $\begin{array}{l}\text { Number of } \\
\text { uncensored } \\
\text { observations }\end{array}$ & 160 & 64 & 96 \\
\hline $\begin{array}{l}\text { Number of left- } \\
\text { censored } \\
\text { observations }\end{array}$ & 135 & 78 & 57 \\
\hline $\begin{array}{l}\text { Number of right- } \\
\text { censored } \\
\text { observations }\end{array}$ & 50 & 15 & 35 \\
\hline
\end{tabular}

Source. - Data are from our own survey.

NoTE. - Numbers in parentheses are standard errors. N.A. = not applicable.

* Significant at the 5\% level (one-tailed test).

** Significant at the $1 \%$ level (one-tailed test) 
outside reduced the NC ratios of export drastically. Finally, the years of top management consistently has a positive and significant effect on NC ratio.

Table 8 presents the results of the estimation of the unit price functions. The first two columns compare the determinants of unit prices of conventional machines and machining centers, using the full sample. In the latter two columns, a comparison is made between the early and the late 1990s regarding the unit prices of machining centers, as the pace of price changes was different for different enterprise groups.

In column 1 of table 8 , no independent variables have significant effects on the unit prices of conventional machine tools, which suggests that the target level of product quality does not depend on the technological and management abilities of the enterprise in the case of conventional machine tools. In contrast, a number of independent variables have statistically significant effects on the unit prices of machining centers, as shown in columns 2-4. Most important, the effects of the three group dummies are negative in all cases and highly significant in the cases of machining centers, which is consistent with our hypothesis 1 that the quality of the original pioneers' products is higher than that of the followers. As is seen from columns 3 and 4, these effects become much smaller in absolute value terms in the later period, except for the new followers, indicating that the original pioneers reduced unit prices more drastically than the followers and the new pioneers. This is consistent with our hypothesis 4 that the original pioneers were the most effective imitators in the 1990s. The result that machining centers made by the new followers have the lowest unit prices is also consistent with our previous argument that their target market is of lower-grade machining centers. Finally, the effect of the first year of machine tool production is generally positive, which suggests that younger enterprises tend to produce machining centers of higher quality.

\section{Conclusion}

While the importance of information spillovers in industrial growth is increasingly recognized among economists, much less is known as to how they take place. To fill the gap, this article distinguishes among the different stages in the innovation-imitation process and among different actors. In the case of the machine tool industry in Taiwan, the fact that many of the followers and the new followers, and even the new pioneers, were spin-offs from the machine tool enterprises strongly suggests the importance of spin-offs as the major source of both innovations and imitations. Although the quantitative evidence is hard to come by, casual observations also suggest a significant role of spinoffs in disseminating technological knowledge and management know-how from one enterprise to another in other industries in East Asia.

Our study indicates that the ability of followers to imitate innovation is limited and, hence, the diversity in productivity among enterprises arises and often persists. Whether an enterprise has low or high productivity and weak or strong ability to imitate is not completely random or unpredictable; instead, there seems to be a clear pattern. Even in the early stages of industrial de- 
TABLE 8

Determinants of Unit Price: Random Effects Estimates

\begin{tabular}{|c|c|c|c|c|}
\hline & $\begin{array}{c}\text { Conventional Machine } \\
\text { (1990-99) } \\
\text { (1) }\end{array}$ & $\begin{array}{c}\text { Machining Center } \\
\text { (1990-99) } \\
\text { (2) }\end{array}$ & $\begin{array}{l}\text { Machining Center } \\
\text { (1990-94) } \\
\text { (3) }\end{array}$ & $\begin{array}{c}\text { Machining Center } \\
\text { (1995-99) } \\
\text { (4) }\end{array}$ \\
\hline Followers & $\begin{array}{l}-.172 \\
(239)\end{array}$ & $-.467 * *$ & $-.516 * *$ & $-.389^{*}$ \\
\hline New pioneers & $\begin{array}{c}-.185 \\
(.404)\end{array}$ & $\begin{array}{c}. .503 * * \\
(.074)\end{array}$ & $\begin{array}{c}-.668^{* *} \\
(.246)\end{array}$ & $\begin{array}{c}-.357^{*} \\
(.206)\end{array}$ \\
\hline New followers & $\begin{array}{c}-.181 \\
(.429)\end{array}$ & $\begin{array}{c}-.716^{* *} \\
(.117)\end{array}$ & N.A. & $\begin{array}{c}-.660 * \\
(.338)\end{array}$ \\
\hline Spin-off & $\begin{array}{c}-.160 \\
(.185)\end{array}$ & $\begin{array}{c}-.035 \\
(.067)\end{array}$ & $\begin{array}{c}-.220 \\
(.196)\end{array}$ & $\begin{array}{c}-.103 \\
(.199)\end{array}$ \\
\hline First year of machine tool production & $\begin{array}{l}.007 \\
(.013)\end{array}$ & $\begin{array}{l}.022 * * \\
(.004)\end{array}$ & $\begin{array}{c}.019 \\
(.012)\end{array}$ & $\begin{array}{l}.024 * \\
(.013)\end{array}$ \\
\hline High school & $\begin{array}{l}.149 \\
(.114)\end{array}$ & $\begin{array}{c}-.043 \\
(.062)\end{array}$ & $\begin{array}{c}-.077 \\
(.154)\end{array}$ & $\begin{array}{l}.064 \\
(.215)\end{array}$ \\
\hline University & $\begin{array}{c}.080 \\
(.133)\end{array}$ & $\begin{array}{l}.170^{* * *} \\
(.058)\end{array}$ & $\begin{array}{l}.298 \\
(.214)\end{array}$ & $\begin{array}{l}.181 \\
(.140)\end{array}$ \\
\hline Outsider & $\begin{array}{c}-.087 \\
(.149)\end{array}$ & $\begin{array}{c}-.191 * * \\
(.070)\end{array}$ & $\begin{array}{c}-.349 \\
(.276)\end{array}$ & $\begin{array}{l}.037 \\
(.092)\end{array}$ \\
\hline Years of top management & $\begin{array}{c}-.003 \\
(.004)\end{array}$ & $\begin{array}{l}.002 \\
(.002)\end{array}$ & $\begin{array}{l}.005 \\
(.003)\end{array}$ & $\begin{array}{l}.005 \\
(.006)\end{array}$ \\
\hline
\end{tabular}

This content downloaded from 210.137.153.113 on January 07, 2016 23:22:49 PM 


\begin{tabular}{|c|c|c|c|c|}
\hline $\begin{array}{l}\text { Year dummies } \\
\text { Constant }\end{array}$ & $\begin{array}{c}\text { Nine dummies for 1991-99 } \\
-7.969 \\
(24.63)\end{array}$ & $\begin{array}{l}\text { Nine dummies for } 1991-99 \\
-38.40^{* *} \\
(7.251)\end{array}$ & $\begin{array}{l}\text { Four dummies for } 1991-94 \\
-31.14 \\
(23.26)\end{array}$ & $\begin{array}{l}\text { Four dummies for } 1996-99 \\
-40.95 \\
(25.97)\end{array}$ \\
\hline \multicolumn{5}{|c|}{ 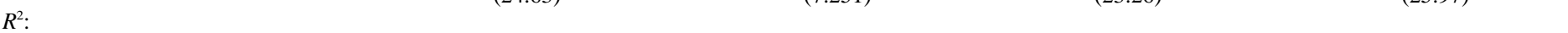 } \\
\hline Within & .121 & .157 & .230 & .151 \\
\hline Overall & .067 & .560 & .623 & .376 \\
\hline$P$ value of Hausman test & .999 & N.A. ${ }^{a}$ & .999 & .267 \\
\hline Number of observations & 288 & 107 & 43 & 64 \\
\hline $\begin{array}{l}\text { Number of observations per } \\
\text { enterprise }\end{array}$ & 8.2 & 5.9 & 3.9 & 4.0 \\
\hline
\end{tabular}

SOURCE. - Data are from our own survey.

NOTE. - The dependent variable is the logarithm of unit price. Numbers in parentheses are standard errors. N.A. $=$ not applicable.

${ }^{a}$ Since the variance of enterprise-specific effect was estimated to be zero, the random-effects estimator degenerated to pooled OLS and Hausman's specification test was not carried out.

* Significant at the $5 \%$ level (one-tailed test)

This content downloaded from 210.137.153.113 on January 07, 2016 23:22:49 PM 
velopment, when production technology is relatively simple, the productivity of imitators tends to be low. When more advanced technology is introduced, new innovative and highly productive entrepreneurs may enter the industry because new types of knowledge and ability may be required for new innovations. Thereafter, another group of imitators enters the industry, and the existing enterprises become imitators. According to the results of our study, in this new stage of development, both old and new followers tend to be less productive than old and new innovators.

Our study also indicates that, because of such diversity and the sequence of changing types of entrants, the role of imitations in industrial development changes over time. While imitation always contributes to the productivity growth of the industry in theoretical models with homogeneous enterprises and perfect imitation, in the real world, with significant heterogeneity of enterprises and imperfect imitation, imitation by new entrants will make an important contribution to the quantitative expansion of the industry and enhance the "collective efficiency" of industrial clusters, ${ }^{28}$ but not necessarily to the productivity growth of the industry as a whole in the early stages of development. The contribution of imitation to productivity growth, however, will assume greater importance in raising the productivity in later stages when the active entry tends to cease. Hence, it seems to us that the changing roles of information spillovers must be carefully examined if we are to identify the mechanism of productivity growth. Indeed, if new industries fledge one after another in a developing economy and go through such early stages of development, then the economy may well have high growth in GDP without significant productivity growth, as with the "high-performing" East Asian economies. We do not necessarily imply, however, that contribution of imitation to overall economic growth is negligible, since imitators must have shifted resources from lower value to higher value industries.

Needless to say, it is hazardous to draw strong conclusions from a single case study. A compilation of further in-depth empirical studies in different industries in different countries is called for in order to elucidate the roles of innovations and imitations in the long-term process of industrial growth.

\section{Notes}

* We appreciate comments and suggestions from Yujiro Hayami, Konosuke Odaka, and other participants at the Foundation for Advanced Studies on International Development (FASID) Hakone Conference, Gustav Ranis, and T. N. Srinivasan, as well as two anonymous referees.

1. Paul M. Romer, "Increasing Returns and Long-Run Growth," Journal of Political Economv 94 (1986): 1002-37; Robert E. Lucas, Jr., "On the Mechanics of Economic Development," Journal of Monetary Economics 22 (1988): 3-42.

2. Alfred Marshall, Principles of Economics: An Introductory Volume (London: Macmillan, 1920); J. V. Henderson, Urban Development: Theory, Fact, and Illusion (New York: Oxford University Press, 1988); H. Schmitz and K. Nadvi, "Clustering and Industrialization," World Development 27 (1999): 1503-14; J. V. Henderson, Zmarak Shalizi, and A. J. Venables, "Geography and Development," Journal of Economic Geography 1 (2001): 81-105; T. Sonobe, D. Hu, and K. Otsuka, "Process of 
Cluster Formation in China: A Case Study of a Garment Town," Journal of Development Studies 39 (2002): 118-39.

3. J. A. Schumpeter, The Theory of Economic Development (New York: Oxford University Press, 1912).

4. Major exceptions include the empirical work on product life cycle by M. Gort and S. Klepper, "Time Paths in the Diffusion of Product Innovations," Economic Journal 92 (1982): 630-53; and S. Klepper and E. Graddy, "The Evolution of New Industries and the Determinants of Market Structure," Rand Journal of Economics 21 (1990): 27-44.

5. See J. Kim and L. J. Lau, "The Source of Economic Growth of the East Asian Newly Industrialized Countries," Journal of the Japanese and International Economics 8 (1994): 235-71; A. Young, "The Tyranny of Numbers: Confronting the Statistical Realities of the East Asian Growth Experience," Ouarterly Journal of Economics 113 (1995): 641-80.

6. H. Pack and L. E. Westphal, "Industrial Strategy and Technological Change: Theory versus Reality,” Journal of Development Economics 22 (1986): 87-128.

7. In this study, we deal only with metal cutting machinery, excluding metal fabricating machinery, because the two are quite different mechanically, although it is not uncommon for them to be grouped together in statistics in Taiwan.

8. Spin-offs are very common in the early stage of cluster-based industrial development in East Asia. See, e.g., Sonobe et al.; and E. Yamamura, T. Sonobe, and K. Otsuka, "Human Capital, Cluster Formation, and International Relocation: The Case of the Garment Industry in Japan, 1968-98," Journal of Economic Geography 3 (2003): 37-56. They are also very important in the motorcycle industry in both Japan and China, according to our ongoing studies.

9. G. Stigler, "The Division of Labor Is Limited by the Extent of the Market," Journal of Political Economy 59 (1951): 185-93.

10. A. H. Amsden, "The Division of Labor Is Limited by the Type of Market: The Case of the Taiwanese Machine Tool Industry," World Development 5 (1977): 217-33, and "The Division of Labor Is Limited by the Rate of Growth of the Market: The Taiwanese Machine Tool Industry in the 1970s," Cambridge Journal of Economics 9 (1985): 271-84.

11. Henderson (n. 2 above); E. L. Glaeser, H. D. Kallal, J. A. Scheinkman, and A. Shleifer, "Growth in Cities," Journal of Political Economv 100 (1992): 1126-52; J. Henderson, V. A. Kuncoro, and M. Turner, "Industrial Development in Cities," Journal of Political Economv 103 (1995): 1067-90; Schmitz and Nadvi (n. 2 above).

12. See H. Schmitz, "Collective Efficiency and Increasing Returns," Cambridge Journal of Economics 23 (1999): 465-83.

13. See M. Fransman, "International Competitiveness, Technical Change, and the State: The Machine Tool Industry in Taiwan and Japan," World Development 14 (1986): 1375-96.

14. This is because parts for conventional milling machines could be used for machining centers and also because the interfirm division of labor was particularly developed in the Taichung cluster for the production of a standardized, conventional milling machine that was a copy of a U.S.-made machine called "Bridgeport."

15. This contrasts with the stylized fact of industry dynamics observed by Gort and Klepper (n. 4 above), in which the time path of enterprise numbers tends to follow an inverted U-shaped curve. In their theoretical account for this nonmonotonic time path, Jovanovic and MacDonald argue that "technological improvement must have reduced production costs" but "it must also have greatly increased the firm's optimal scale so that firm numbers had to shrink over time" (p. 325). See also B. Jovanovic and G. H. MacDonald, "The Life Cycle of a Competitive Industry," Journal of Political Economy 102 (1994): 322-47; Klepper and Graddy (n. 4 above); and S. Klepper, 
"Entry, Exit, Growth, and Innovation over the Product Life Cycle," American Economic Review 86 (1996): 562-83.

16. The TFP index is the Tornqvist type. In the computation of capital stock, we assumed that equal amounts of nominal net investments were made each year during the period between 2 census years. The estimated nominal investments were deflated by the wholesale price index of machinery and equipment. We added estimated real values of net investment to the real book value of capital stock as of 1954 .

17. Finer but similar decomposition formulas are discussed by M. N. Bailey, C. Hulten, and D. Campbell, "Productivity Dynamics in Manufacturing Plants," Brookings Papers on Economic Activity: Microeconomics, 1992 (Washington, D.C.: Brookings Institution, 1992), pp. 187-267; Z. Griliches and H. Regev, "Firm Productivity in Israeli Industry, 1979-1988," Journal of Econometrics 65 (1995): 175-203; B. Y. Aw, X. Chen, and M. J. Roberts, "Firm-Level Evidence on Productivity Differentials and Turnover in Taiwanese Manufacturing," Journal of Development Economics 66 (2001): $51-86$.

18. See Amsden, "The Division of Labor Is Limited by the Rate of Growth of the Market."

19. See Bailey et al.

20. Note that, because of the lack of production data in the 1970s and the early 1980s, the followers are included in incumbents in the current estimation of TFP index shown in table 1 .

21. Since our sample enterprises are all survivors from 1991 to 1999, selection bias may arise. According to the industrial census, the rate of survival was fairly high in the metal cutting machinery industry: out of 1,915 enterprises existing in 1991, 1,562 enterprises survived in 1996, with a survival rate of $82 \%$. We believe that this survival rate underestimates the true survival rate of machine-tool producing enterprises under study because small part-suppliers, which enter and exit the industry more frequently, are included in the metal cutting industry.

22. We owe this point to Yuji Furukawa of Tokyo Metropolitan University, who is a major expert on machine tool technologies in Japan.

23. In our data, the export as well as the production of products other than machine tools are not included.

24. While it is true that the unit prices of NC machines are affected by the quality of controllers, it is also true that high-quality controllers tend to be attached to mechanically superior machines.

25. While schooling of the current managers can be considered as predetermined, years of top management may be endogenous. Thus, we reestimated all the functions without this variable and found that the estimated coefficients of remaining variables are largely unchanged qualitatively, except for the new pioneer dummy in table 7, where its coefficients are significantly negative for 1990-94 and significantly positive for 1995-99. Such differences, however, do not affect the substance of our analysis.

26. We adopted this specification because this allows us to compare the performance of the old and new pioneers directly in the regression analysis. The qualitative results remain unchanged, however, even if the spin-off dummy assumes unity for the two new pioneers.

27. B. E. Honoré, "Trimmed LAD and Least Squares Estimation of Truncated and Censored Regression Models with Fixed Effects," Econometrica 60 (1992): 533-65.

28. H. Schmitz (n. 12 above), and "Collective Efficiency: Growth Path for SmallScale Industry," Journal of Development Studies 31 (1995): 529-66. 